\title{
The Role of Language Style, Perceived Services and Medical Qualities on the Tourism Development in Malaysia: Mediating Role of Customer Satisfaction
}

\author{
Muhammad Azeem Ahmad ${ }^{a}$, Arshia Hashmi ${ }^{b}$, Kiran Shehzadi ${ }^{c}$, Muhammad Atif Nawaz ${ }^{\text {d }}$ \\ ${ }^{a}$ Assistant Professor, Barani Institute of Sciences, Pakistan \\ Email: azeem@baraniinstitute.edu.pk \\ b Assistant Professor, The University of Faisalabad, Pakistan \\ Email: arshia.hashmi@tuf.edu.pk \\ ${ }^{c}$ Visiting Faculty, Department of English, Government Sadiq College Women University, Bahawalpur, \\ Pakistan \\ Email: kiranshehzadilodhi@gmail.com \\ d Department of Economics, the Islamia University of Bahawalpur, Pakistan \\ Email: atif.nawaz.baloch@gmail.com
}

\begin{tabular}{l}
\hline ARTICLE DETAILS \\
\hline History: \\
Accepted o7 March 2021 \\
Available Online 31 March 2021 \\
\hline Keywords: \\
Perceived Services Quality, \\
Perceived Medical Quality, \\
Language Style, Perceived \\
Tourism Development, Customer \\
Satisfaction
\end{tabular}

JEL Classification:

L16, L19, M59

DOI: $10.47067 /$ reads.v7i1.316

\begin{abstract}
Recently, tourism development is considered a significant factor to enhance the economic growth of the country and has gained the attention of upcoming studies and regulators. Thus, the present research examines the impact of perceived service quality, perceived medical quality, and language style on the perceived tourism development in Malaysia. The current research also investigated the mediating impact of customer satisfaction among the nexus of perceived services quality, perceived medical quality, language style, and perceived tourism development in Malaysia. This study has used the quantitative method of data collection and also used the smart-PLS to examines the relationships among the variables. The results revealed that perceived service quality, perceived medical quality, and language style has a positive association with perceived tourism development in Malaysia. The findings also indicated that customer satisfaction positively mediated among the relationships of perceived services quality, perceived medical quality, language style, and perceived tourism development in Malaysia. This study has guided to policymakers while formulating the policies related to tourism development that enhance economic development.
\end{abstract}

(C) 2021 The authors. Published by SPCRD Global Publishing. This is an open access article under the Creative Commons Attribution-

NonCommercial 4.0

Corresponding author's email address: azeem@baraniinstitute.edu.pk

\section{Introduction}

In many businesses, the role of culture prevails with dominant importance. It helps to uplift the perceived requirements mandatory for the industry of tourism. Although, many Malaysian tourism 


\section{Review of Economics and Development Studies, Vol. 7 (1) 2021, 25-36}

companies have inserted various measures to enable the perceived tourism development. But the certainty of various factors related to qualities and services are asserting a significant role in the development of tourism in Malaysia. Among the cultural elements, the style of language asserts dominating role for the perceived development of tourism with the collaboration of other corresponding factors. Those corresponding elements are discussed with the perceived medical and service qualities inducing a significant impact on the development of tourism in Malaysia. Mostly, the culture prevails in the service environment but the customer satisfaction also states its importance with the perceived approach. With the judgment of customers, it could be easier to analyze the quality of service that is perceived among the general public. The views of people have been ascertained in the context of service providers which are dominating due to quality and perceived service (Shabbir, Malik Shahab, \& Janjua Saquib, 2017). Language style extends the effectiveness and efficiency of communication facilities to be provided to the public for enhancing the perceived tourism development in Malaysia. It is upon the experiences which have been availed by the activities of language process for uplifting tourism development. Various opportunities have been explored while emphasizing the improvement of local languages in different tourism activities (Whitney-Squire, Wright, \& Alsop, 2018).

People in most countries like Malaysia are more curious about their health. Therefore, the perceived quality is the most dominating element emphasized by many countries. This states the importance of perceived medical quality inserting an impact on perceived tourism development. In modeling the structures of perceived medical quality, the industry of tourism has achieved considerable rise (Sadeh \& Garkaz, 2019). Generally, the satisfaction of customers is the primary aim of every company to enhance their performance as well as profits. Therefore, the perceived tourism development has attained a competitive advantage by the insertion of certain elements which could contribute toward industry in Malaysia. It is dependent on the men and women for better customer satisfaction and hospitality and tourism are the main prospects to be analyzed (Koc, 2020). It is dependent on the facilities of tourism which are introduced in the country or outside. It is also obvious that enhancing tourism development could also be perceived by the approach of contribution to the economy. This states the vital role of sustainability which prevails among the development of tourism as well as the other factors like perceived medical and service quality with language style. There is a dominance of subjective happiness and perception of tourism development (Ganji, Johnson, \& Sadeghian, 2020). Therefore, it could better analyze the perception of tourism development which helps in maintaining the resident happiness.

The tourism industry in Malaysia started to grow in the late 196os. Up to 1970, the tourism industry was not considered a significant economic activity since the contribution of primary resources such as rubber and tin was much greater. The Malaysian government started developing the tourism industry in 1970 with the aim of growing foreign exchange sales, increasing job opportunities and wages, promoting regional growth, diversifying the economy, and rising government revenue. TDC (Tourism Development Corporation of Malaysia) was established in 1972 and is responsible for the development of tourism in Malaysia. TDC was not a priority at the time due to financial constraints. In 1987, the Ministry of Culture, Arts, and Tourism was created. This Ministry helps to support the sector by offering benefits, enhancing the standard of basic amenities, and developing a more detailed policy. The ministry was later moved to the Malaysian Ministry of Tourism, where it remains today. After manufacturing and commodities, tourism is the third-largest contributor to Malaysia's GDP. In 2018, this industry contributed around 5.9\% of the overall GDP. The tourism industry in Southeast Asia has grown significantly in recent years, and Malaysia was eager to take advantage of this development. The "Visit Genuinely Asia Malaysia 2020" initiative was initiated with the aim of meeting the optimistic 2020 goals of 30 million visitors and 100 billion Malaysian ringgit in tourism receipts. However, due to 
Review of Economics and Development Studies, Vol. 7 (1) 2021, 25-36

the outbreak of COVID-19, this campaign has been canceled. The number of tourists who visit from 2007 to 2020 is given in Figure 1.

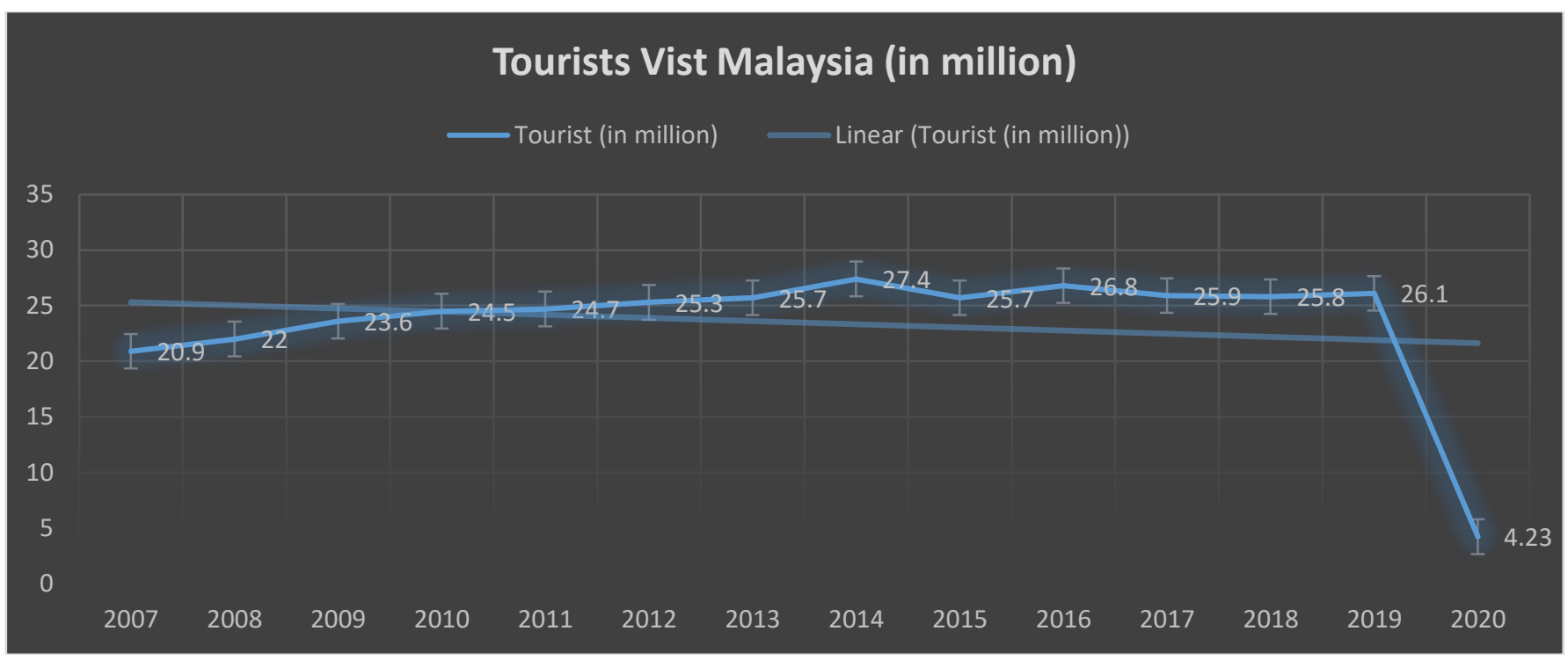

\section{Figure 1: Number of Tourists who visited Malaysia from 2007 to 2020}

Numerous studies have been conducted on Malaysian tourism with several factors but the literature gap does exist regarding the combination of factors like services, language, and most important medical facilities in a single study in order to develop the Malaysian tourism industry. This study will address this gap. This investigation will help both the tourist as well as policymakers in different ways. For instance, tourists will understand Malaysian tourism in a better way like language barriers, etc. Other the other hand will also help the policymakers to understand the issues associated with this industry and also to design tourism-friendly policies. Finally will also shine the spotlight on the importance of the tourism industry's contribution to the Malaysian economy.

\section{Literature Review}

In the competitive environment, most of the tourism companies of Malaysia are working with numerous efforts to succeed for perceived quality. This could be possible by the way of inducing proper measurement which is placing a significant impact on the perceived tourism development of Malaysia. In the Malaysian tourism industry, the perceived tourism development has attained considerable rise by the introduction of perceived service quality. The present views of different industries have ascertained the service qualities and have revealed significant facets for customer satisfaction and perceived development (Kant \& Jaiswal, 2017). This is a clear indication of various contributions which are positive for the development of perceived tourism among developed countries. In Malaysia, most of the service providers of the tourism industry, customer attraction is considered as a primary objective. This elaborates the importance of customer satisfaction among other competitors which strives for better performance. Therefore, the quality of services, as well as perceived service quality, are better tools to measure the level of perceived tourism development. Different roles are analyzed with a competent view of perceived service quality. This stated the building of customer satisfaction which induces roles of justice perception and customer trust (Cheng, Chen, Yen, \& Teng, 2017). There is a significant relationship between cooperation, customer satisfaction, and customer trust.

H1: Perceived service quality significantly influences the perceived tourism development.

The language style is a denomination of facilities that are essential for the upbringing of tourism 


\section{Review of Economics and Development Studies, Vol. 7 (1) 2021, 25-36}

development (Shehzadi, 2018). This states the compulsory requirement of perceived tourism development which attracts more tourists. The familiarity of foreign people due to the effectiveness of language style cover most of the areas which are countered as a barrier to the tourism development (Shehzadi \& Krishnasamy, 2018). Tourism is an essential need of every business for exploring new innovative ideas through the choices of language and opportunity (Schneider, 2018). Tourism activities are linked with various economic conditions and therefore have a significant impact on the development of tourism. With the familiarity of language style, the perceived tourism development could also be enumerated by the prevalence of other corresponding elements. These elements are contributing a significant portion toward the perceived tourism development usually in Malaysia. Most of the Malaysian tourism industries have attained significant growth by implementing an effective language style. There is a variation of products that usually enhances the perceived tourism development. The impacts of customer engagement and halal tourism are directly linked with the effects of religiosity (Abror, Wardi, Trinanda, \& Patrisia, 2019). Although, many perceived supports have been availed by the tourism development extended by the customer satisfaction.

H2: Language style significantly influences the perceived tourism development.

The satisfaction of patients is the primary aim of every country due to the high level of tourism activities. This is positive devotion to tourism development because of the significant response of customers toward health facilities in other countries like Malaysia. It is the future choices of tourism countries like Malaysia which enhances the capable measures to develop perceived tourism. Different programs have been introduced that could enhance the customary level or toward the qualitative implementation (Redlener et al., 2018). Many countries like Malaysia have adapted improvement procedures for the growth of perceived tourism development. The importance of perceived tourism development is considerably increased by the development of perceived medical quality. Many countries like Malaysia are found of capabilities for perceived tourism development (Chaudhry, Nazar, Ali, Meo, \& Faheem, 2021). Therefore, the effective strategic implementation of perceived medical quality is induced as an important measure to raise tourism development in developing countries. The impacts are ascertained by the behaviors of customer engagement and customer satisfaction which induces a positive impact on industries (Vo, Chovancová, \& Tri, 2020). These industries are more crucial about the engagement of people and behaviors of people which increases the tourism development.

H3: Perceived medical quality significantly influences the perceived tourism development.

With the indulging factors of customer satisfaction, a significant mediating role is played among the perceived service quality and perceived tourism development. It is only possible due to the effective inducement of customer satisfaction measures which could bring positive change among the related factors of the tourism industry (Sun et al., 2020). The impacts of perceived tourism development and perceptions of tourism desires have been dominant in residential people (Wu, Kim, \& Wong, 2020). Some dimensions of perceived service quality have endorsed a significant impact on Malaysian tourism development. This states the gross effects which are rendered by the satisfaction and quality measures. Joint efforts place a positive influence upon the perceived tourism development in Malaysia with the considerable dominance of perceived service quality. While revisiting the efforts of perceived service quality, many dimensions have been uncovered for a variety of people (El Alfy \& Abukari, 2020). While understanding the tourism development, the perceived approach has been increased among the tourism businesses. These are the main contributing role of customer satisfaction which have been endorsed by the perceived tourism development and perceived service quality. Cultural differences are related to tourist satisfaction and attitudes of languages in Malaysia tourism sectors (de Carlos, Alén, PérezGonzález, \& Figueroa, 2019).

H4: Customer satisfaction significantly and positively mediates among perceived service quality and 
perceived tourism development.

Businesses of the tourism industry have achieved considerable gain after the inducement of language style which has raised the customer satisfaction level. This also widely contributed toward the perceived tourism development usually in Malaysia. After the placement of attachment and images, the support and value of tourism development significantly enhance (Oh \& Kim, 2017). Within this, the language style positively illustrates its impact on the perceived tourism development because the ultimate response of customers is prevalent on language style. The orientation of activities is endorsed by the ways of language style which is rendered by the level of customer satisfaction. There is an importance of literacy in knowledge to get familiar with the places of tourism in a literary manner (Jiang \& Yu, 2020). Perceived tourism development is widely related to customer satisfaction because of the interfered role of language style (Nawaz et al., 2020). This devoted significant measures upon the tourism development which is prevalent on the customer satisfaction and proper budgeting. While indulging the loyalty and complaints, the customer satisfaction could be enhanced by the attachments of the exhibition which are rendered by language styles (Zhan, Luo, \& Luo, 2020).

H5: Customer satisfaction significantly and positively mediates among language style and perceived tourism development.

Significant linkage has been elaborated among the perceived medical quality and perceived tourism development. Therefore, many countries like Malaysia have introduced medical qualities for the stability of perceived tourism development. The establishment of casinos in tourism development impacts the sustainability of tourism measures (D. Lee, Kim, Han, \& Wong, 2020). With the enhancement of perceived medical quality, the impact on perceived tourism development is certain. Therefore, effective policies are required to be induced in the tourism industry to counter the aftershocks of medical quality which could impact the development of perceived tourism (Nawaz et al., 2021). The value of medical quality is certain in many tourism industries due to variation of risks and fees (Habibi \& Ariffin, 2019). This is an indication of quality experience as well as the negative and positive implications. While countering the aftershocks, the prevalence of customer satisfaction is significantly linked with perceived tourism development and perceived medical quality. It is stated by the implementation of health care facilities which are prominent for the rising temperature of tourism all around the world. Numerous attributes are certain with the relevance of customer satisfaction usually in businesses (W. S. Lee, Moon, \& Song, 2018).

H6: Customer satisfaction significantly and positively mediates among perceived medical quality and perceived tourism development.

\section{Research Methods}

The research examines the impact of perceived services quality, perceived medical quality, and language style on the perceived tourism development and also investigates the mediating impact of customer satisfaction among the nexus of perceived services quality, perceived medical quality, language style, and perceived tourism development in Malaysia. This study has used the quantitative method of data collection and used the questionnaires for this purpose. The data has been gathered from the tourist from different countries by using questionnaires. These respondent has been selected randomly and forwarded the surveys by personal visit to the high tourism locations in Pakistan. Out of total 550 distributed questionnaires, about 410 were used for the analysis purpose with 74.55 percent rate of response.

This research has used the smart-PLS to examine the relationships among the variables and investigate the discriminant and convergent validity. The complexity of the framework and hypotheses 
testing purpose of the study is the basic reasons to adopt the smart-PLS for the analysis. The present study has taken perceived tourism development (PTD) as a dependent variable with six items, while customer satisfaction (CS) has been adopted as the mediating variable with ten items. Finally, this study has adopted three independent variables such as perceived services quality (PSQ) with six items, perceived medical quality (PMQ) with three items, and language style (LS) with five items. These links and variables are shown in Figure 2.

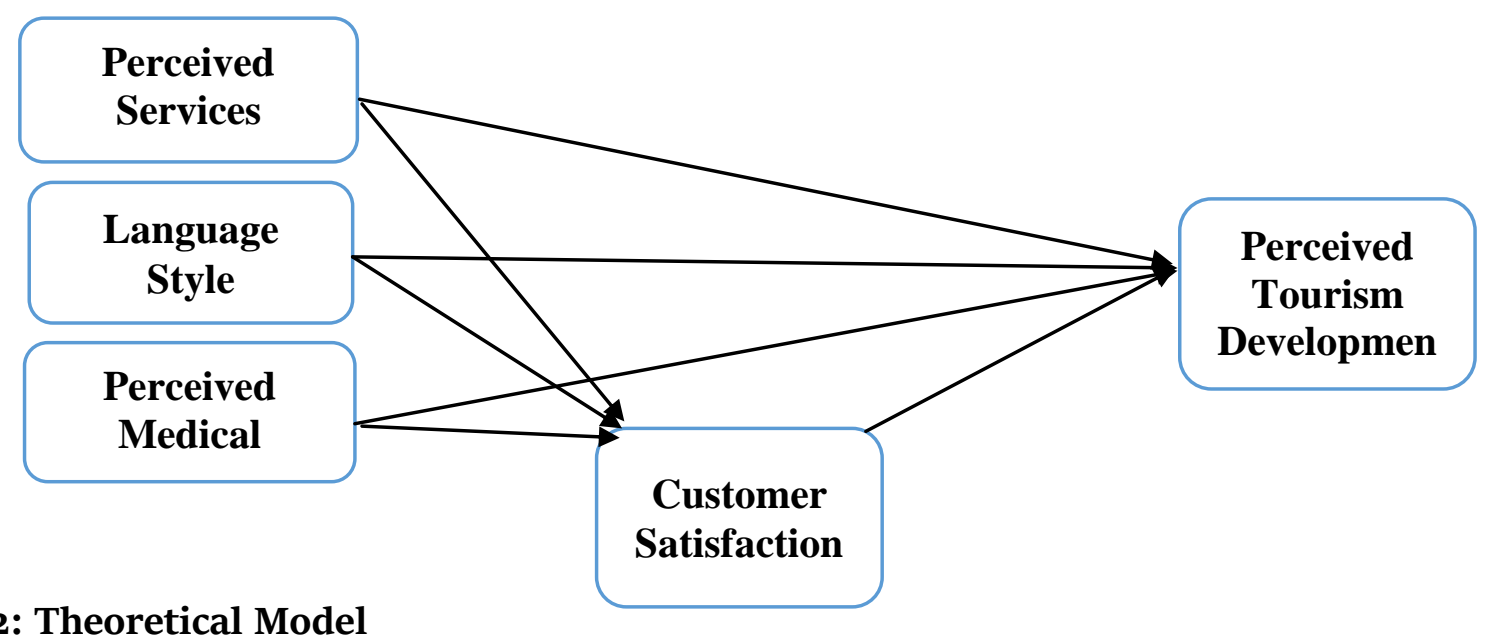

Figure 2: Theoretical Model

\section{Findings}

This study has examined the relationships between the items and known as convergent validity and the part of measurement model assessment. The figures have shown that the CR and Alpha values are not lower than 0.70 , and the loadings and AVE values are not smaller than 0.50. These values have exposed that the relationships among items are very high and valid convergent validity. These values are highlighted in Table 1.

Table 1: Convergent Validity

\begin{tabular}{|l|l|l|l|l|l|}
\hline Constructs & Items & Loadings & Alpha & CR & AVE \\
\hline Customer Satisfaction & CS1 & 0.877 & 0.917 & 0.932 & 0.635 \\
\hline & CS10 & 0.735 & & & \\
\hline & CS2 & 0.657 & & & \\
\hline & CS3 & 0.806 & & & \\
\hline & CS5 & 0.781 & & & \\
\hline & CS6 & 0.905 & & & \\
\hline & CS7 & 0.718 & & & \\
\hline & CS9 & 0.862 & & & \\
\hline & LS1 & 0.858 & 0.838 & 0.889 & 0.621 \\
\hline & LS2 & 0.657 & & & \\
\hline & LS3 & 0.890 & & & \\
\hline & LS4 & 0.902 & & & \\
\hline & LS5 & 0.578 & & & \\
\hline Perceived Medical Qualities & PMQ1 & 0.906 & 0.710 & 0.790 & 0.563 \\
\hline & PMQ2 & 0.671 & & & \\
\hline & PMQ3 & 0.646 & & & \\
\hline Perceived Services Qualities & PSQ1 & 0.840 & 0.911 & 0.930 & 0.689 \\
\hline
\end{tabular}


Review of Economics and Development Studies, Vol. 7 (1) 2021, 25-36

\begin{tabular}{|l|l|l|l|l|l|}
\hline & PSQ2 & 0.892 & & & \\
\hline & PSQ3 & 0.794 & & & \\
\hline & PSQ4 & 0.720 & & & \\
\hline & PSQ5 & 0.835 & & & \\
\hline Perceived Tourism Development & PSQ6 & 0.888 & & & 0.564 \\
\hline & PTD1 & 0.732 & 0.807 & 0.865 & \\
\hline & PTD2 & 0.683 & & & \\
\hline & PTD4 & 0.746 & & & \\
\hline & PTD5 & 0.838 & & & \\
\hline & PTD6 & 0.746 & & & \\
\hline
\end{tabular}

This study has also examined the relationships between the variables that are known as discriminant validity and also the part of measurement model assessment. The figures have shown that the Heterotrait and Monotrait (HTMT) ratios are not larger than 0.85 . These values have exposed that the relationships among variables are very low and valid discriminant validity. These values are highlighted in Table 2.

Table 2: Discriminant Validity

\begin{tabular}{|l|l|l|l|l|l|}
\hline & CS & LS & PMQ & PSQ & PTD \\
\hline CS & & & & & \\
\hline LS & 0.763 & & & & \\
\hline PMQ & 0.600 & 0.711 & & & \\
\hline PSQ & 0.278 & 0.456 & 0.461 & & \\
\hline PTD & 0.653 & 0.697 & 0.779 & 0.444 & \\
\hline
\end{tabular}

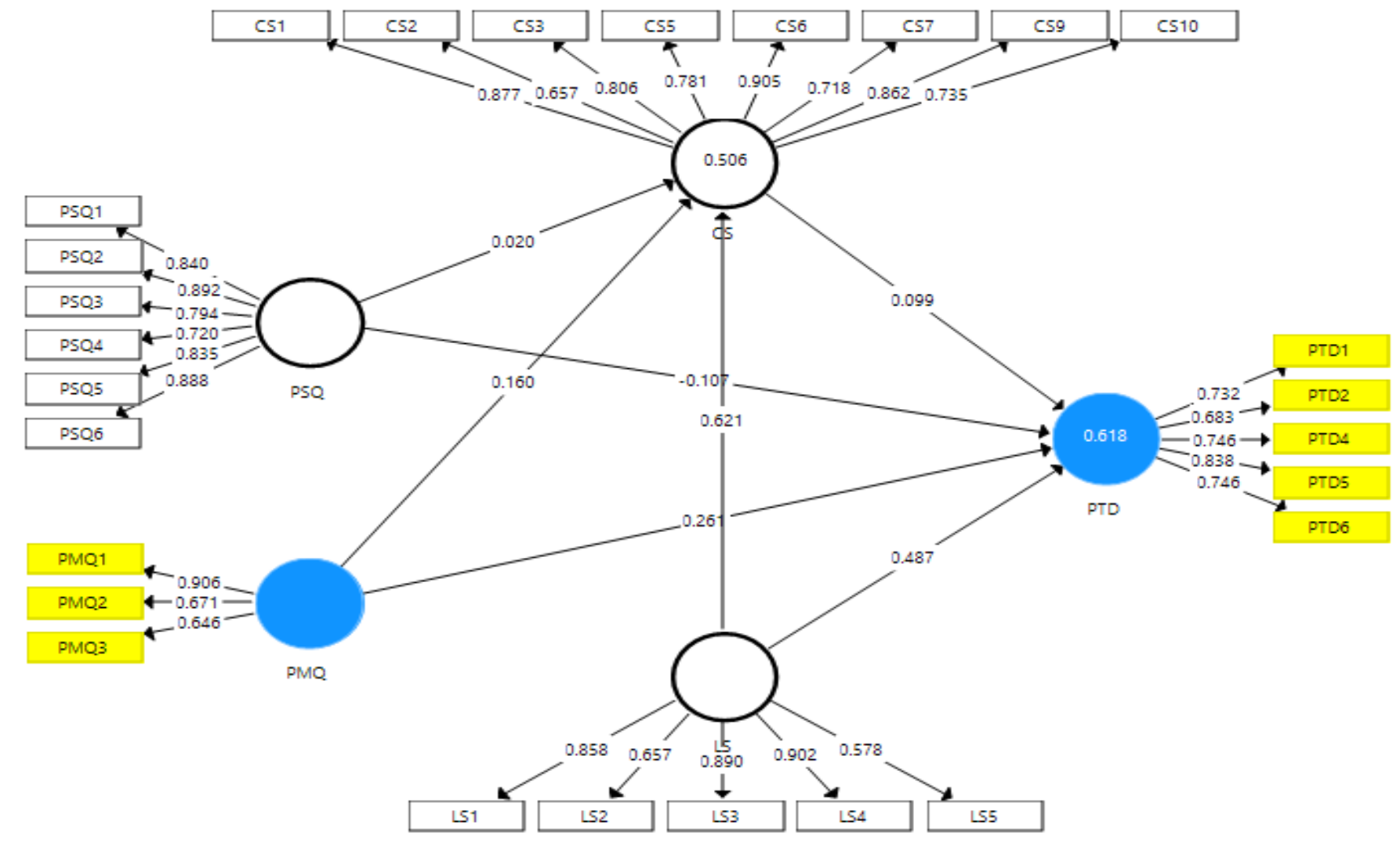

Figure 3: Measurement Model Assessment 
Review of Economics and Development Studies, Vol. 7 (1) 2021, 25-36

Finally, the relationships among the constructs have been examined that are part of structural model assessment. The results revealed that perceived service quality perceived medical quality, and language style have a positive association with perceived tourism development in Malaysia and accept $\mathrm{H} 1, \mathrm{H}_{2}$, and $\mathrm{H}_{3}$. In addition, the findings also indicated that customer satisfaction positively mediated among the relationships of perceived services quality, perceived medical quality, language style, and perceived tourism development in Malaysia and accept $\mathrm{H}_{4}, \mathrm{H}_{5}$ and $\mathrm{H} 6$. These relationships are highlighted in Table 3.

\section{Table 3: Path Analysis}

\begin{tabular}{|l|l|l|l|l|l|l|}
\hline Relationships & Beta & S.D. & T Statistics & P Values & L.L. & U.L. \\
\hline CS -> PTD & 0.099 & 0.056 & 1.767 & 0.040 & 0.016 & 0.198 \\
\hline LS -> PTD & 0.487 & 0.097 & 5.002 & 0.000 & 0.332 & 0.627 \\
\hline PMQ -> PTD & 0.261 & 0.059 & 4.454 & 0.000 & 0.171 & 0.361 \\
\hline PSQ -> PTD & 0.107 & 0.051 & 2.089 & 0.020 & 0.192 & 0.531 \\
\hline LS -> CS -> PTD & 0.062 & 0.034 & 1.790 & 0.038 & 0.009 & 0.124 \\
\hline PMQ -> CS -> PTD & 0.026 & 0.011 & 2.364 & 0.024 & 0.003 & 1.035 \\
\hline PSQ -> CS -> PTD & 0.022 & 0.006 & 3.667 & 0.014 & 0.011 & 1.012 \\
\hline
\end{tabular}

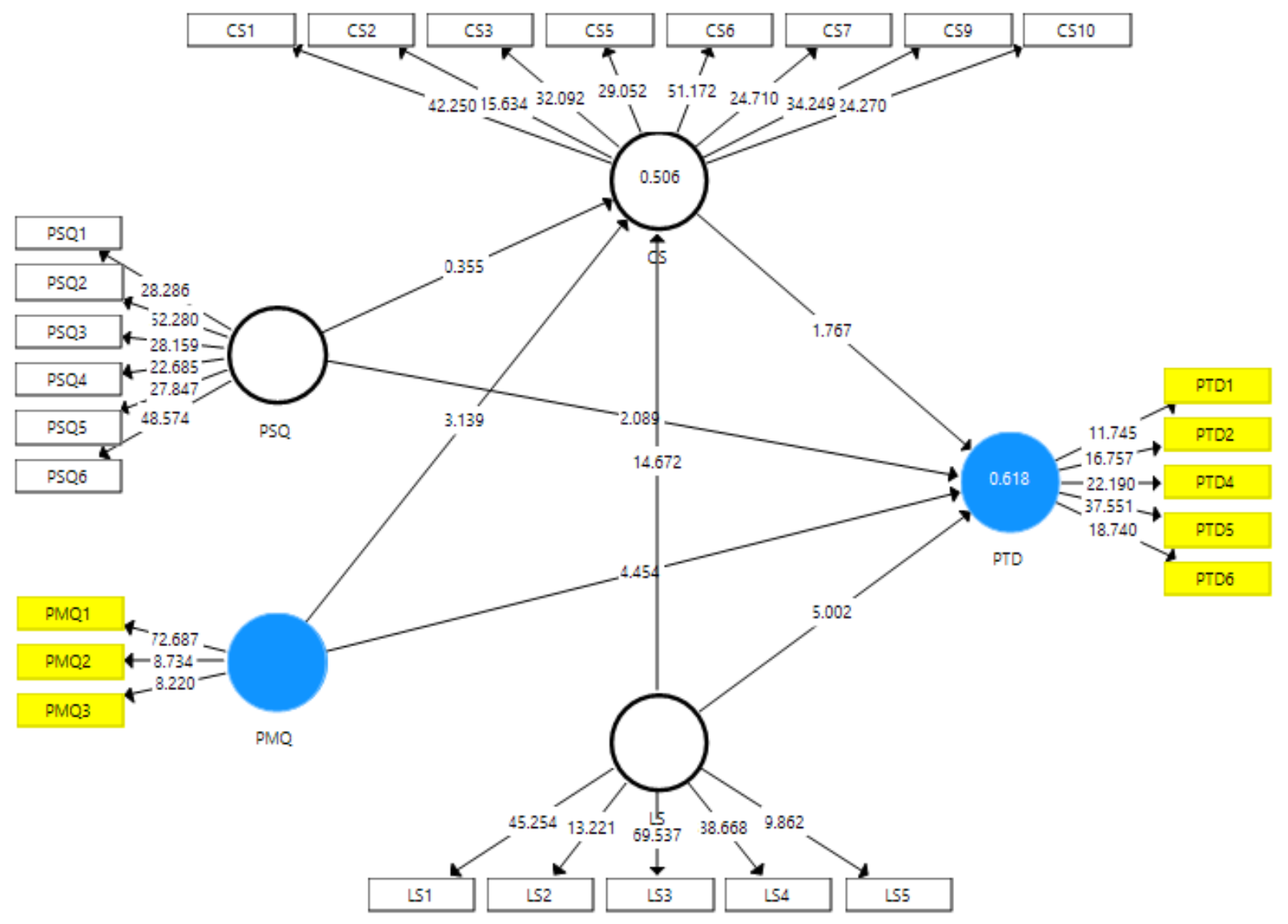

Figure 4: Structural Model Assessment

\section{Discussions and Implications}

The study results have revealed that perceived service quality has a positive relationship with perceived tourism development. The success of tourism is dependent on the satisfaction of tourists towards the quality of services provided by the concerned tourism company. If the tourists find the 


\section{Review of Economics and Development Studies, Vol. 7 (1) 2021, 25-36}

service quality of tourism according to their requirements, all the matters relevant to tourism are managed in a better way, and the perceived company's development is high. These results are in line with the past study of Suess, Baloglu, and Busser (2018). This industry examines tourism management and tourism service quality (tourism performance). This study states when the tourists are satisfied with the services provided by tourism, the company promotes, and management gets more serious about its functions to improve the service quality. The study results have also revealed that language style has a positive relationship with perceived tourism development. Tourism is an industry that provides its services both at the national and international level, and it includes many activities almost related to all social, economic, cultural, and geographical areas. As language is essential to communication, the language style affects the perceived tourism development. These results are in line with the past study of Liu, Dou, Li, and Cai (2020), which indicates that the tourism company where the management adopts the convenient and respectful language style, it becomes easy for the management to carry its functions, as in this way it finds a positive response from the stakeholders and industry develops. The results have indicated that the perceived medical quality has a positive relationship with the perceived tourism development. The stakeholders' perception of the high quality of medical services provided by the tourism companies motivates all the stakeholders to cooperate with the management in its different functions, and it develops tourism. These results are supported by the past study of Park, Lee, Yoo, and Nam (2016), which shows that the tourism company which takes care of the health of the stakeholders gives a better medical facility to its workers and tourists. It benefits tourism in two ways. First, the company personnel takes an active part in their functions, and the tourists who are satisfied with the medical services of tourism-company promotes it.

Moreover, the study results have revealed that the customers' satisfaction plays a mediating role between the customers' perception of service quality and perceived tourism development. These results are approved by the past study of Lin, Chen, and Filieri (2017), which indicates that emotive satisfaction is developed in the customers when the customers perceive that the tourism company takes care of their facility and give them good quality services. This emotive satisfaction results in a high rise in marketing and high financial position. The results have also indicated that the customers' satisfaction is a significant mediator between the language style and perceived tourism development. These results are approved by the past of Moghavvemi, Woosnam, Hamzah, and Hassani (2020), which indicates that the customers' satisfaction is developed by the adoption of convenient and respective language style adopted and this high customers' satisfaction results in the high rate of tourism development. In addition, the study results have shown that the customers' satisfaction is a considerable mediator between the perceived medical quality and the perceived tourism development. This study is approved by the previous study of Abror et al. (2019).

This study has a remarkable theoretical significance. It contributes a lot to the literature on the economy as it deals with the perceived tourism development. The study throws ample light on the influences of three social factors like perceived service quality, language style, and perceived medical service on the perceived development of tourism-company. This study also makes a great contribution to the existing literature with the introduction of customers' satisfaction as a mediator between perceived service quality, language style, and perceived medical service and the perceived tourism development. The study also has an empirical implication along with the theoretical implication. This literary work out is a guideline to the tourism management in an emerging economy and the government as it leads to ways how to accelerate the rate of tourism development and how to improve the image of the local tourism industry. It guides that the perceived tourism development can be accelerated through the high perception of service quality, easy-to-understand and respectful language style, and the customer's perception of medical quality. 
Review of Economics and Development Studies, Vol. 7 (1) 2021, 25-36

\section{Conclusion and Limitations}

Our study analyses that the customers' perception of high-quality services from the tourismcompany accelerates the perceived tourism development. The tourism company makes rapid development when the customers have much satisfaction towards the services provided by the company. The study also implies that the language style adopted by the tourism representatives influences the perceived tourism development. Tourism is a large industry encompassing a wide range of activities, and it provides services both to local people and foreigners. The language, which is essential of communication between company representatives and outsiders, must be easy to perceive and respective so that the overall performance of the tourism industry is high. The customers (tourists) who depend on the survival and development of the tourism, when having the perception that the tourism company is providing them good medical services, they prefer the tourism services of this company. Thus, the tourism company's perceived development is high. The customers' perception of better general services and medical services from the tourism-company and the use of easily perceived and respective language for communication with the customers' enhance the customers' satisfaction and thereby accelerate the perceived tourism development.

The current study has a number of limitations that must be filled by scholars in the future at the time, replicating the proposition of this study. The scope of this study is limited because the author has addressed a number of factors like perceived services, language style, and perceived medical services, which may affect the perceived tourism development. Whereas there are a number of economic and geographical elements which have deep impacts on the perceived tourism development, but all these elements have no place in this study. It is recommended to the scholars in the future to enhance the scope of the study with the introduction of some other drivers of perceived tourism development. This study examines the perceived tourism development in Malaysia which have geographical characteristics, economic conditions, and social standard different countries. In this way, this study is equally suitable for other countries. Future authors must also talk about the tourism industry of some other countries to overcome this problem.

\section{References}

Abror, A., Wardi, Y., Trinanda, O., \& Patrisia, D. (2019). The impact of Halal tourism, customer engagement on satisfaction: moderating effect of religiosity. Asia Pacific Journal of Tourism Research, 24(7), 633-643. doi:10.1080/10941665.2019.1611609

Chaudhry, I. S., Nazar, R., Ali, S., Meo, M. S., \& Faheem, M. (2021). Impact of environmental quality, real exchange rate and institutional performance on tourism receipts in East-Asia and Pacific region. Current Issues in Tourism, 1-21. doi:https://doi.org/10.1080/13683500.2021.1894101

Cheng, J.-C., Chen, C.-Y., Yen, C.-H., \& Teng, H.-Y. (2017). Building customer satisfaction with tour leaders: the roles of customer trust, justice perception, and cooperation in group package tours. Asia Pacific Journal of Tourism Research, 22(4), 395-407. doi:10.1080/10941665.2016.1271816

de Carlos, P., Alén, E., Pérez-González, A., \& Figueroa, B. (2019). Cultural differences, language attitudes and tourist satisfaction: a study in the Barcelona hotel sector. Journal of Multilingual and Multicultural Development, 40(2), 133-147. doi:10.1080/01434632.2018.1493114

El Alfy, S., \& Abukari, A. (2020). Revisiting perceived service quality in higher education: uncovering service quality dimensions for postgraduate students. Journal of Marketing for Higher Education, 30(1), 1-25. doi:10.1080/08841241.2019.1648360 


\section{Review of Economics and Development Studies, Vol. 7 (1) 2021, 25-36}

Ganji, S. F. G., Johnson, L. W., \& Sadeghian, S. (2020). The effect of place image and place attachment on residents' perceived value and support for tourism development. Current Issues in Tourism, 2, 1-15. doi:10.1080/13683500.2020.1784106

Habibi, A., \& Ariffin, A. A. M. (2019). Value as a medical tourism driver interacted by experience quality. Anatolia, 30(1), 35-46. doi:10.1080/13032917.2018.1496122

Jiang, L., \& Yu, L. (2020). Consumption of a literary tourism place: a perspective of embodiment. Tourism Geographies, 22(1), 127-150. doi:10.1080/14616688.2019.1586985

Kant, R., \& Jaiswal, D. (2017). The impact of perceived service quality dimensions on customer satisfaction: An empirical study on public sector banks in India. International Journal of Bank Marketing, 35(3), 411-430. doi:10.1108/IJBM-04-2016-0051

Koc, E. (2020). Do Women Make Better in Tourism and Hospitality? A Conceptual Review from A Customer Satisfaction and Service Quality Perspective. Journal of Quality Assurance in Hospitality \& Tourism, 21(4), 402-429. doi:10.1080/1528008X.2019.1672234

Lee, D., Kim, S., Han, H., \& Wong, A. K. F. (2020). Casino tourism development is blessing or curse? Assessment of casino tourism impacts and suggestions for sustainable casino tourism development. Asia Pacific Journal of Tourism Research, 25(11), 1168-1184. doi:10.1080/10941665.2020.1837891

Lee, W. S., Moon, J., \& Song, M. (2018). Attributes of the coffee shop business related to customer satisfaction. Journal of Foodservice Business Research, 21(6), 628-641. doi:10.1080/15378020.2018.1524227

Lin, Z., Chen, Y., \& Filieri, R. (2017). Resident-tourist value co-creation: The role of residents' perceived tourism impacts and life satisfaction. Tourism Management, 61, 436-442. doi:https://doi.org/10.1016/j.tourman.2017.02.013

Liu, C., Dou, X., Li, J., \& Cai, L. A. (2020). Analyzing government role in rural tourism development: An empirical investigation from China. Journal of Rural Studies, 79, 177-188. doi:https://doi.org/10.1016/j.jrurstud.2020.08.046

Moghavvemi, S., Woosnam, K. M., Hamzah, A., \& Hassani, A. (2020). Considering Residents' Personality and Community Factors in Explaining Satisfaction with Tourism and Support for Tourism Development. Tourism Planning \& Development, 13, 1-27. doi:https://doi.org/10.1080/21568316.2020.1768140

Nawaz, M. A., Hussain, M. S., Kamran, H. W., Ehsanullah, S., Maheen, R., \& Shair, F. (2020). Trilemma association of energy consumption, carbon emission, and economic growth of BRICS and OECD regions: Quantile regression estimation. Environmental Science and Pollution Research, 1-15.

Nawaz, M. A., Seshadri, U., Kumar, P., Aqdas, R., Patwary, A. K., \& Riaz, M. (2021). Nexus between green finance and climate change mitigation in N-11 and BRICS countries: empirical estimation through difference in differences (DID) approach. Environmental Science and Pollution Research, 28(6), 6504-6519.

Oh, H., \& Kim, K. (2017). Customer satisfaction, service quality, and customer value: years 200o2015. International Journal of Contemporary Hospitality Management, 29(1), 2-29. doi:10.1108/IJCHM-10-2015-0594

Park, J. H., Lee, C., Yoo, C., \& Nam, Y. (2016). An analysis of the utilization of Facebook by local Korean governments for tourism development and the network of smart tourism ecosystem. International Journal of Information Management, 36(6), 1320-1327. doi:https://doi.org/10.1016/j.ijinfomgt.2016.05.027

Redlener, M., Olivieri, P., Loo, G. T., Munjal, K., Hilton, M. T., Potkin, K. T., . . Braithwaite, S. A. (2018). National Assessment of Quality Programs in Emergency Medical Services. Prehospital Emergency Care, 22(3), 370-378. doi:10.1080/10903127.2017.1380094 
Review of Economics and Development Studies, Vol. 7 (1) 2021, 25-36

Sadeh, E., \& Garkaz, M. (2019). Interpretive structural modeling of quality factors in both medical and hospitality services in the medical tourism industry. Journal of Travel \& Tourism Marketing, 36(2), 253-267. doi:10.1080/10548408.2018.1527273

Schneider, B. (2018). Lobster, tourism and other kinds of business. Economic opportunity and language choice in a multilingual village in Belize. Language and Intercultural Communication, 18(4), 390-407. doi:10.1080/14708477.2018.1474887

Shabbir, A., Malik Shahab, A., \& Janjua Saquib, Y. (2017). Equating the expected and perceived service quality: A comparison between public and private healthcare service providers. International Journal of Quality \& Reliability Management, 34(8), 1295-1317. doi:10.1108/IJQRM-04-2016-0051

Shehzadi, K. (2018). ESL writing anxiety, writer's native language, ESL writing self-efficacy and ESL writing performance: Insights into the literature. Pakistan Journal of Humanities and Social Sciences, 6(2), 221-247.

Shehzadi, K., \& Krishnasamy, H. (2018). Dynamics of ESL Writing Performance: A Theoretical Framework. Pakistan Journal of Humanities and Social Sciences, 6(1), 144-159.

Suess, C., Baloglu, S., \& Busser, J. A. (2018). Perceived impacts of medical tourism development on community wellbeing. Tourism Management, 232-245. doi:https://doi.org/10.1016/j.tourman.2018.06.006

Sun, H., Awan, R. U., Nawaz, M. A., Mohsin, M., Rasheed, A. K., \& Iqbal, N. (2020). Assessing the socio-economic viability of solar commercialization and electrification in south Asian countries. Environment, Development and Sustainability, 1-23.

Vo, N. T., Chovancová, M., \& Tri, H. T. (2020). The Impact of E-service Quality on the Customer Satisfaction and Consumer Engagement Behaviors Toward Luxury Hotels. Journal of Quality Assurance in Hospitality \& Tourism, 21(5), 499-523. doi:10.1080/1528008X.2019.1695701

Whitney-Squire, K., Wright, P., \& Alsop, J. (2018). Improving Indigenous local language opportunities in community-based tourism initiatives in Haida Gwaii (British Columbia, Canada). Journal of sustainable tourism, 26(2), 173-191. doi:10.1080/o9669582.2017.1327535

Wu, H., Kim, S., \& Wong, A. K. F. (2020). Residents' perceptions of desired and perceived tourism impact in Hainan Island. Asia Pacific Journal of Tourism Research, 25(6), 583-601. doi:10.1080/10941665.2020.1752749

Zhan, F., Luo, W., \& Luo, J. (2020). Exhibition attachment: effects on customer satisfaction, complaints and loyalty. Asia Pacific Journal of Tourism Research, 25(6), 678-691. doi:10.1080/10941665.2020.175426 